\title{
The State and Trends of Enterprises Efficiency on the Basis of Modern Indicators
}

\author{
Yurty M. DeReV'Yanko ${ }^{i}$, OlHa A. LuKashii, \\ Marina A. Litsmaniii, Alona O. Svitlychna ${ }^{i v}$
}

\begin{abstract}
One of the most relevant approaches for determining the company performance is rightly considered the attractiveness of the company in terms of investing in it and receiving remuneration from the owners or managers of the company. From these positions, we can distinguish four groups of performance analysis indicators: growth indicators (revenue / sales, net profit, EBIT, EBITDA, FCF and OCF, CAPEX (OPEX); performance indicators (ROE, EBIT margin, EBITDA margin, Net Income margin); indicators of condition assessment (multipliers and underestimation) (EV/EBITDA, P/E, P/BV, FCF Yield, FCF/MC, EV/Revenue, Div Yield); debt burden indicators and risks (Net Debt/EBITDA, Equity/Assets, St Deviation, Beta). The current state of development of the Ukrainian economy requires the use of appropriate analysis tools that allow you to objectively assess the current state of business and assess the dynamics of changes that have occurred before. We have chosen the analysis period from 2013 to 2019 to assess the changes that have taken place during this period, which began in a relatively stable economic situation and escalated into a strong economic crisis caused primarily by events in eastern Ukraine and the annexation of Crimea. The purpose of assessing the state of development and attractiveness of Ukrainian enterprises is to verify the fact of overcoming the active phase of the crisis of 2014-2016. To this end, we focused on the analysis of leading companies in Sumy region, because they had close ties with the Russian Federation, with a rather mediocre level of business development, and therefore may be a kind of indicator of the average state of the national economy. The analysis of companies on the selected key indicators indicates that the crisis has been largely overcome, but a number of indicators of some companies indicate that the crisis began before the tragic events of early 2014.
\end{abstract}

Keywords: efficiency, enterprise, indicator, management.

Introduction and research task. The last 7 years of Ukraine's economic development have been very difficult for business development. The crisis that began in early 2014 has had a negative impact on all sectors of the economy for quite some time. However, according to a number of experts, negative trends began to take shape before the crisis and military conflict in eastern Ukraine in 2014. This is evidenced by a number of surveys of companies and entrepreneurs in recent years, including the Global Competitiveness Report. In our opinion, to prove or disprove such conclusions it is necessary to analyse the activities and indicators of companies over this period of time. In addition, it is equally important to get an answer to a very important question, whether the business overcame the active phase of the crisis of 2014-2016

${ }^{i}$ Yuriy M. Derev'yanko, C.Sc. (Economics), Associated Professor of Department of Economics and BusinessAdministration, Sumy State University;

${ }^{i i}$ Olha A. Lukash, C.Sc. (Economics), Associated Professor of Department of Economics and BusinessAdministration, Sumy State University;

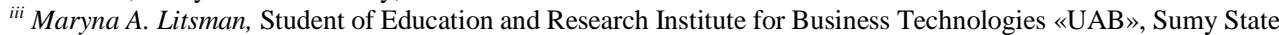
University;

${ }^{i v}$ Alona O. Svitlychna, Student of Education and Research Institute for Business Technologies «UAB», Sumy State University.

(C) Yuriy M. Derev`yanko, Olha A. Lukash, Maryna A. Litsman, Alona O. Svitlychna, 2020.

https://doi.org/10.21272/mer.2020.87.09

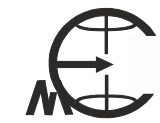


Yuriy M. Derev yanko, Olha A. Lukash, Maryna A. Litsman, Alona O. Svitlychna. The State and Trends of Enterprises Efficiency on the Basis of Modern Indicators

and whether it returned to pre-crisis levels of activity. In view of this, the analysis of the state of enterprises and their investment attractiveness is an important research to understand the current situation, in particular in Sumy region, as the region is borderline and has always belonged to regions with average and below average level of economic development.

\section{Research publications}

There is a significant amount of qualitative research and publications on the analysis of the state of development of companies on various indicators, including: Bahatska, 2014; Davydov, 2017; Kindratska, 2017; Luchko, 2016; Finansovyy, 2016. Almost all research use comprehensive and very detailed methods. The main problems identified during the analysis of the analysed tools proposed by scientists are: limited access to sources of information required for the calculation and too time-consuming analysis process, which is often not justified. After analysing the current areas of analysis, we tried to identify from existing approaches and methods, only those that are reliable, clearly understandable and accessible for practical use.

\section{Research method and results}

Nowadays analysis of enterprises performance indicators, which are the basis of their analysis and decision-making, as well as investment attractiveness are formally can be divided into 4 groups. It is a: growth indicators (Revenue/Sales, Net Profit, EBIT/EBITDA, FCF and OCF, CAPEX (OPEX); performance indicators (ROE, EBIT margin, EBITDA margin, Net Income margin); indicators of condition assessment (multipliers and underestimation) (EV/EBITDA, P/E, P/BV, FCF Yield, FCF/MC, EV/Sales, Div Yield); debt burden indicators and risks (Net Debt/EBITDA, Equity/Assets, St Deviation, Beta).

Among the firms' economic performance indicators that are widely used on practice are: Sales (Revenue); Net Profit (NP); Return on Equity (ROE); Earnings Before Interest and Taxes (EBIT); Earnings Before Interest, Taxes, Depreciation and Amortization (EBITDA); EBITDAto-sales ratio (EBITDA margin); Free Cash Flow (FCF); Free Cash Flow Yield (FCF Yield); enterprise value to earnings before interest, taxes, depreciation, and amortization ratio (EV/EBITDA); Net Debt-to-EBITDA Ratio (Net Debt/EBITDA).

To calculate these indicators in accordance to the Ukrainian financial forms of companies' statement we used such standard documents of financial reporting (Financial Statement): Form 1 (Ф1) - "Balance Sheet”; Form 2 (Ф2) - "Statement of Financial Results”; Form 3 (Ф3) - "Statement of Cash Flows". Sales (Revenue), Net Profit (NP) and EBIT can be taken directly form enterprises financial statements. Sales (Revenue) is $\Phi 2(2000)$, Net Profit (NP) $=$ $\Phi 2(2350 / 2355)$ and EBIT $=$ Ф2(2190/2195).

Earnings Before Interest and Taxes (EBIT) takes a company’s revenue, or earnings, and subtracts its cost of goods sold and operating expenses. The resulting figure, EBIT, is also called "operating earnings," "operating profit," or "operating income." Another way to calculate EBIT is to take net income and add back the interest and taxes the company paid. Investors can find the data required to calculate EBIT on the company's income statement. If EBIT is unsatisfactory, the company will need to either increase its revenues, decrease its expenses or both to improve its performance.

$$
E B I T=E B T+I n t,
$$

where EBT - earnings before tax; Int - interest payable (interest on loans, but not credit body).

Return on Equity (ROE) is a measure of a company's annual return (net income) divided by the value of its total shareholders' equity, expressed as a percentage.

$$
R O E=N I / E \text {, }
$$

where NI - net income; $E$ - equity. Due to Ukrainian Financial Statements (UFS): NI (net income) $=\Phi 2(2350 / 2355), \mathrm{E}$ (equity) $=\Phi 1(1495)$. 
Return on Equity is a two-part ratio in its derivation because it brings together the income statement and the balance sheet, where net income or profit is compared to the shareholders' equity. The number represents the total return on equity capital and shows the firm's ability to turn assets into profits. To put it another way, it measures the profits made for each dollar from shareholders' equity.

Earnings Before Interest, Taxes, Depreciation and Amortization (EBITDA) is a metric used to evaluate a company's operating performance. It can be seen as a proxy for cash flow from the entire company's operations.

$$
E B I T D A=E B I T+A,
$$

where $E B I T$ - earnings before interest and taxes; $A$ - depreciation (amortization). Due to UFS: $\mathrm{EBITDA}=\Phi 2(2190 / 2195)+\Phi 2(2515)$.

It is intended to allow a comparison of profitability between different companies.

EBITDA-to-sales ratio (EBITDA margin) - profitability ratio that measures how much in earnings a company is generating before interest, taxes, depreciation, and amortization, as a percentage of revenue. With its help, we can estimate the profitability of the enterprise (excluding depreciation, taxes and interest payments) in as a part of revenue. When calculating this ratio, you can use the following formula:

$$
\text { EBITDA margin = EBITDA } / \text { Revenue }
$$

Due to UFS: EBITDA margin = [Ф2(2190/2195) + Ф2(2515)] / Ф2 (2000).

The coefficient is best assessed in the dynamics: growth - is a positive phenomenon, decline - may be a negative phenomenon, or additional analysis is needed.

When calculating EBITDA, concepts such as “depreciation” and “interest” are generally used. Both indicators in the accounting is sometimes quite ambiguously calculated. Different experts, even using the same formula, can get different results. This can be manipulative in the presentation of information that may mislead, for example, a potential investor.

Free cash flow (FCF) represents the cash for a certain period that the company has at its disposal after investing in the maintenance or expansion of its asset base (capex). Sometimes this indicator may indicate the amount of company funds that will be used to pay dividends. The FCF is sometimes referred to as "absolutely free funds".

The most common calculation option is relatively simple: we have to deduct from the earned funds the cost of maintaining the company. The result is an amount that can be "taken out" from the business without harming it. Free cash flow in the Statement of Cash Flows (as in other standard financial statements) is not calculated and does not have a clearly defined method of calculation. The simplest and basic algorithm (method) for calculating FCF is as follows:

$$
\text { FCF }=\text { Net operating cash flow }- \text { Investments (capital expenditures) }
$$

Due to UFS: $F C F=\Phi 3(3195)-\Phi 3(3260)$.

The second method - is more complex, which reveals in more detail the reasons for the change in free cash flow has the following calculation:

FCF $=$ EBITDA - income tax expenses - capital expenditures (capex) - net working capital change (NWC)

The third method is similar to the second, but it is used for forecasting purposes and has the following calculation:

FCF $=$ NOPAT + depreciation/amortization - capital expenditures (capex) - net working capital change (NWC) 
Yuriy M. Derev yanko, Olha A. Lukash, Maryna A. Litsman, Alona O. Svitlychna. The State and Trends of Enterprises Efficiency on the Basis of Modern Indicators

Thus, the free cash flow (FCF) reflects the amount of money that the company earns from operating activity. In contrast to profit, FCF shows how well a company is able to generate cash flows (excluding "paper income") that can be used for the following purposes: dividends payments, buyback of shares from the stock exchange, debt repayment, M\&A agreements, purchase of non-core assets, saving money.

There are two types of free cash flow: Free Cash Flow to Firm (FCFF) and Free Cash Flow to Equity (FCFE).

1. FCFF is an indicator that analyses the movement of cash within the core business without taking into account fixed capital investment. In fact, FCFF = FCF, and it gives an understanding of how much financial resources the company has after capital expenditures. Investors more often use this indicator.

2. FCFE is the money that remains after expenses in the company's core business, tax payments and bank interest. This indicator is used to assess the value of the company by shareholders.

Free Cash Flow Yield (FCF Yield -) is the return on free cash flow (FCF), which indicates how much cash that can be distributed to shareholders, the business earns, compared to the value of the company (including: the cost of equity and the cost of debt or just equity). The higher the return, the more payments shareholders can expect.

$$
\text { FCF Yield }=\text { FCF / MC }
$$

where $M C$ (market cap) - the market capitalization of the company or the company value. Due to UFS: FCF Yield = [Ф3 (3195) - Ф3 (3260)] / Ф1 (1495).

Of course, the most accurate way to calculate MC comes from the market valuation of the company's shares needed to determine the value of the company or its market capitalization. If the company's shares are not freely traded on the market, or there are other restrictions, an approximate (simplified) way to calculate this indicator is to use for this purpose the value of the company's equity plus the value of its debt or only the value of equity.

Multiplier of the enterprise value to EBITDA ratio (EV/EBITDA - enterprise value to earnings before interest, taxes, depreciation, and amortization ratio is the ratio of the value of the company (Enterprise Value, EV) to its profit before interest, income tax and depreciation EBITDA (Earnings before interest, taxes, depreciation and amortization). Calculated by the formula:

$$
\frac{E V}{E B I T D A}=\frac{M C+\text { Total Debt }-C}{\text { EBITDA }}
$$

where $M C$ (market cap) is the market capitalization of the company (which is standardly defined as the total market value of the company's shares in circulation, but under certain restrictions and assumptions we can take it equal to the value of the company's equity, MC = Equity $\Phi 1(1495)$; Total Debt - the total value of long-term and short-term debt of the company $\Phi 1(1510)+\Phi 1(1600)$; $C$ - the amount of cash and cash equivalents $\Phi 1(1165)$. Due to UFS:

$$
\frac{E V}{E B I T D A}=\frac{\Phi 1(1495)+\Phi 1(1510)+\Phi 1(1600)-\Phi 1(1165)}{\Phi 2(2190 / 2195)+\Phi 2(2515)}
$$

The EV/EBITDA multiplier belongs to the group of income multipliers and indicates for what period of time unspent on depreciation and payment of interest and income taxes the company will recoup the cost of acquiring the company. It provides an opportunity to compare the company with other companies in the industry, to understand its underestimation, as well as to find the Terminal Value of the company (it is a value in the post-forecast period). The multiplier allows you to compare companies with different debt and tax burdens, ie to abstract from the firm capital structure and features of taxation.

The value of the EV/EBITDA multiplier also depends on the industry, as it is characterized by a higher value for fast-growing companies and a lower value for mature companies. If the 
Ю. М. Дерев'янко, О. А. Лукаш, М. А. Ліцман, А. О. Світлична.

Стан та тенденції ефективності діяльності підприємств на основі сучасних індикаторів

EV/EBITDA of the analyzed company is lower than the industry average, then its shares can be considered at least undervalued. Basically, provided that the EV/EBITDA value is $<3$, the company is considered undervalued. The smaller the value, the more return the investor will receive on the invested capital.

Multiplier Net Debt to EBITDA Ratio (Net Debt / EBITDA) is the company's debt ratio, which demonstrates the ability to pay for existing loans and borrowings. In essence, the ratio of Net Debt to EBITDA indicates how long time a company will need to operate in current cash flow to repay its own debts. Calculation:

$$
\frac{\text { Net Debt }}{\text { EBITDA }}=\frac{\text { Total Debt }-C}{\text { EBITDA }}
$$

Due to UFS:

$$
\frac{\text { Net Debt }}{E B I T D A}=\frac{\Phi 1(1510)+\Phi 1(1600)-\Phi 1(1165)}{\Phi 2(2190 / 2195)+\Phi 2(2515)}
$$

It is assumed that the value of the Net Debt / EBITDA ratio should not exceed 3 . This means that the company has no excessive debt and is able to service its debt obligations. If simpler, the lower the value of the coefficient, the better it is. You also need to remember the numerator and denominator of the indicator. If the multiplier is negative, if the EBITDA value is negative, the company is unprofitable. If the net debt is negative, then the company either has no loans and borrowings, or a large amount of cash, and it can be positive.

Due to above mentioned set of indicators we analysed 6 most well-known valuable companies from Sumy Region: PJCS “Bel Shostka Ukraine” / BELU (ПрАТ «Бель Шостка Україна»), PJCS “Mondelez Ukraine” / MDLZ (ПрAТ «Монделіс Україна»), PJCS “Sumy Food Products Factory” / SFPF (ПрАТ «Сумський завод продовольчих товарів»), PJCS "VNDIkompressormash” / VNDI (ПрАТ «ВНДІкомпресормаш»), JCS “Nasosenergomash Sumy” / NEMS (ПАT «Сумський завод насосного та енергетичного машинобудування «Насосенергомаш»), PJCS “Теchnologia” / TECH (ПрАТ «Технологія»). All data used for analysis was collected from companies' official web-sites and Stock market infrastructure development agency of Ukraine (SMIDA). Growth indicators (Net Profit, EBITDA, FCF) are presented on Table 1.

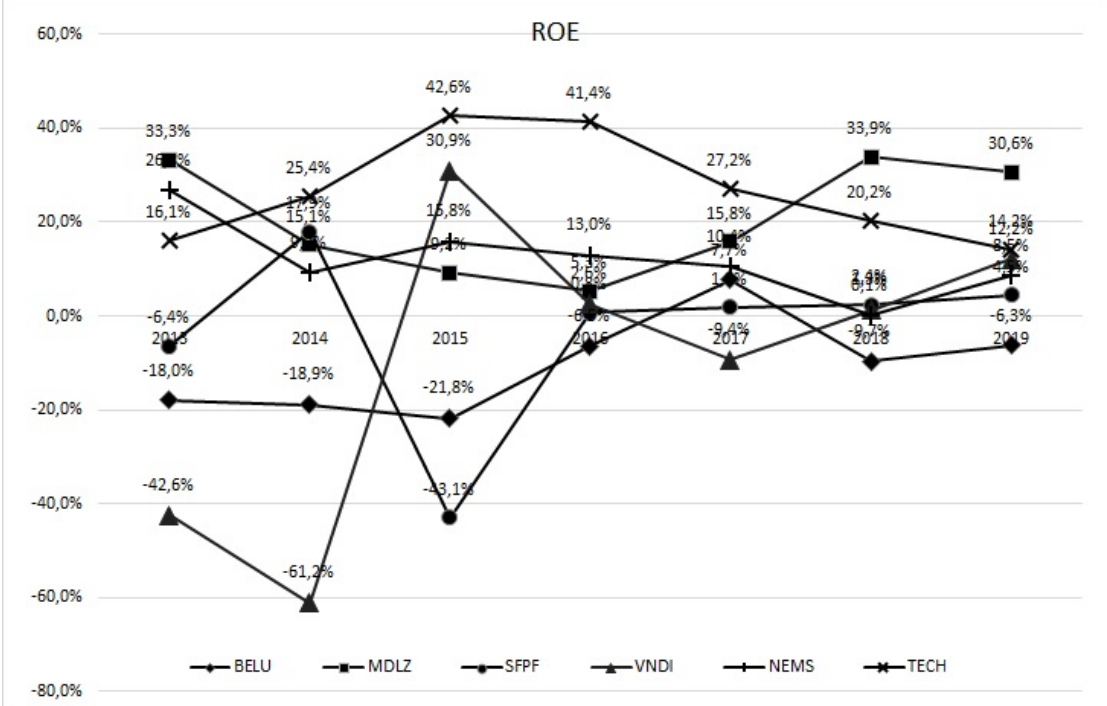

Figure 1 - ROE for BELU, MDLZ, SFPF, VNDI, NEMS, TECH in 2013-2019 
Yuriy M. Derev yanko, Olha A. Lukash, Maryna A. Litsman, Alona O. Svitlychna. The State and Trends of Enterprises Efficiency on the Basis of Modern Indicators

Table 1 - Growth Indicators for BELU, MDLZ, SFPF, VNDI, NEMS, TECH in 2013-2019

\begin{tabular}{c|r|r|r|r|r|r|r|r|}
\hline \multirow{2}{*}{ Company } & \multicolumn{10}{|c|}{ Net Profit } & \multirow{2}{*}{ Sparkline } \\
\cline { 2 - 9 } & \multicolumn{1}{|c|}{2013} & \multicolumn{1}{|c|}{2014} & \multicolumn{1}{c|}{2015} & \multicolumn{1}{c|}{2016} & \multicolumn{1}{c|}{2017} & \multicolumn{1}{c|}{2018} & \multicolumn{1}{c|}{2019} & \\
\hline BELU & $-29226,00$ & $-49141,00$ & $-46587,00$ & $-13058,00$ & 16779,00 & $-11417,00$ & $-6857,00$ & \\
\hline MDLZ & 514564,00 & 276249,00 & 171307,00 & 99094,00 & 277737,00 & 539874,00 & 563997,00 & \\
\hline SFPF & $-911,00$ & 2355,00 & $-6525,00$ & 148,00 & 1414,00 & 1777,00 & 3452,00 & \\
\hline VNDI & $-14347,00$ & $-12794,00$ & 9347,00 & 2164,00 & $-6987,00$ & 311,00 & 3054,00 & \\
\hline NEMS & 177144,00 & 68110,00 & 137905,00 & 129776,00 & 114269,00 & 1441,00 & 102508,00 & \\
\hline TECH & 35575,00 & 68691,00 & 200885,00 & 283103,00 & 241015,00 & 223794,00 & 183326,00 & \\
\hline
\end{tabular}

\begin{tabular}{|c|r|r|r|r|r|r|r|l|}
\hline \multirow{2}{*}{ Company } & \multicolumn{9}{|c|}{ EBITDA } & \multirow{2}{*}{ Sparkline } \\
\cline { 2 - 8 } & \multicolumn{1}{|c|}{2013} & \multicolumn{1}{|c|}{2014} & \multicolumn{1}{c|}{2015} & \multicolumn{1}{c|}{2016} & \multicolumn{1}{c|}{2017} & \multicolumn{1}{c|}{2018} & \multicolumn{1}{c|}{2019} & \\
\hline BELU & $-1163,00$ & $-9133,00$ & $-17230,00$ & 9621,00 & 44382,00 & 15571,00 & 20044,00 & \\
\hline MDLZ & 760637,00 & 510382,00 & 278653,00 & 184223,00 & 444150,00 & 791465,00 & 874984,00 & \\
\hline SFPF & $-489,00$ & 4738,00 & $-2305,00$ & $-1846,00$ & 6407,00 & 11413,00 & 18321,00 & \\
\hline VNDI & $-7476,00$ & 800,00 & 24226,00 & 12612,00 & 13640,00 & 22239,00 & 24102,00 & \\
\hline NEMS & 266464,00 & 207292,00 & 285916,00 & 264784,00 & 213235,00 & 77150,00 & 216826,00 & \\
\hline TECH & 69068,00 & 120349,00 & 256142,00 & 342316,00 & 354944,00 & 383116,00 & 303569,00 & \\
\hline
\end{tabular}

\begin{tabular}{c|r|r|r|r|r|r|r|l|}
\hline \multirow{2}{*}{ Company } & \multicolumn{10}{|c|}{ FCF } & \multirow{2}{*}{ Sparkline } \\
\cline { 2 - 9 } & \multicolumn{1}{|c|}{2013} & \multicolumn{1}{|c|}{2014} & \multicolumn{1}{c|}{2015} & \multicolumn{1}{c|}{2016} & \multicolumn{1}{c|}{2017} & \multicolumn{1}{c|}{2018} & \multicolumn{1}{c|}{2019} & \\
\hline BELU & $-26853,00$ & $-87495,00$ & $-17306,00$ & 16668,00 & 4766,00 & 15573,00 & 17063,00 & \\
\hline MDLZ & 470805,00 & 358744,00 & 138752,00 & 12346,00 & 265829,00 & 776615,00 & 160732,00 & \\
\hline SFPF & $-297,00$ & $-15920,00$ & $-947,00$ & $-23881,00$ & $-35733,00$ & $-43342,00$ & $-13909,00$ & \\
\hline VNDI & 12489,00 & 10508,00 & $-12448,00$ & $-12473,00$ & $-18902,00$ & $-4228,00$ & 20564,00 & \\
\hline NEMS & $-22963,00$ & $-20879,00$ & 88223,00 & 111998,00 & $-36835,00$ & 61113,00 & $-45737,00$ & \\
\hline TECH & 16894,00 & 30964,00 & $-19238,00$ & 85426,00 & $-59358,00$ & $-116195,00$ & 42301,00 & \\
\hline
\end{tabular}

Performance indicators (ROE, EBIT margin, EBITDA margin) are presented on Figures 1 and Figure 2.

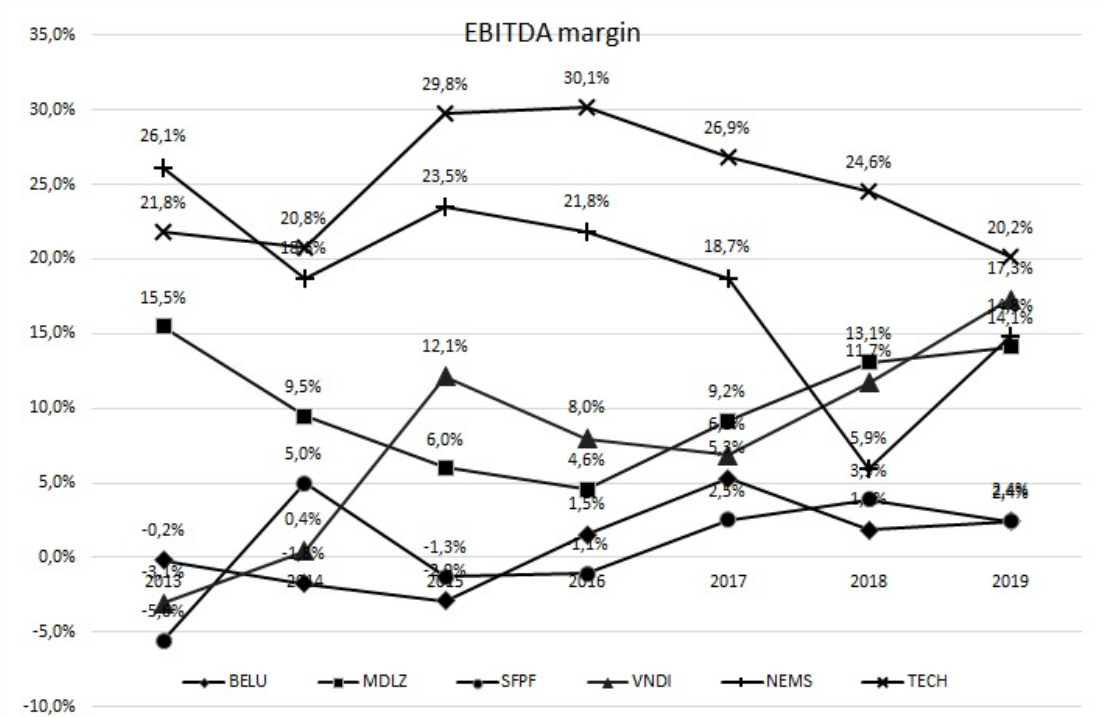

Figure 2 - EBITDA margin for BELU, MDLZ, SFPF, VNDI, NEMS, TECH in 2013-2019 
Ю. М. Дерев'янко, О. А. Лукаш, М. А. Ліцман, А. О. Світлична.

Стан та тенденції ефективності діяльності підприємств на основі сучасних індикаторів

Condition (EV/EBITDA) and debt (Net Debt/EBITDA) indicators are presented on Table 2.

Table 2 - Condition and debt indicators for BELU, MDLZ, SFPF, VNDI, NEMS, TECH

\begin{tabular}{|c|c|c|c|c|c|c|c|}
\hline \multirow{2}{*}{ Company } & \multicolumn{7}{|c|}{ EV/EBITDA } \\
\hline & 2013 & 2014 & 2015 & 2016 & 2017 & 2018 & 2019 \\
\hline BELU & $-169,6$ & $-33,2$ & $-16,4$ & 27,2 & 6,3 & 3,9 & 1,8 \\
\hline MDLZ & 1,5 & 2,0 & 5,8 & 8,8 & 3,6 & 1,7 & 2,0 \\
\hline SFPF & $-28,8$ & 3,9 & $-11,0$ & $-11,7$ & 11,4 & 8,3 & 6,8 \\
\hline VNDI & $-4,4$ & 29,8 & 1,5 & 8,2 & 12,4 & 5,6 & 4,8 \\
\hline NEMS & 2,3 & 3,1 & 2,7 & 3,5 & 4,9 & 12,7 & 5,3 \\
\hline TECH & 3,2 & 2,3 & 1,8 & 2,1 & 2,6 & 3,3 & 4,6 \\
\hline \multirow{2}{*}{ Company } & \multicolumn{7}{|c|}{ EV/EBITDA } \\
\hline & 2013 & 2014 & 2015 & 2016 & 2017 & 2018 & 2019 \\
\hline BELU & $-30,1$ & $-4,8$ & $-4,0$ & 6,3 & 1,4 & $-3,6$ & $-3,7$ \\
\hline MDLZ & $-0,5$ & $-1,5$ & $-0,9$ & $-1,3$ & $-0,4$ & $-0,3$ & $-0,1$ \\
\hline SFPF & 0,2 & 1,1 & $-4,4$ & $-1,6$ & $-0,1$ & 1,7 & 2,6 \\
\hline VNDI & 0,1 & 3,6 & 0,2 & 1,5 & 7,0 & 4,5 & 3,7 \\
\hline NEMS & $-0,1$ & $-0,4$ & $-0,3$ & $-0,3$ & $-0,3$ & $-1,5$ & $-0,3$ \\
\hline TECH & 0,0 & 0,1 & $-0,0$ & 0,1 & 0,1 & 0,5 & 0,3 \\
\hline
\end{tabular}

Results, conclusions and further discussions. Based on the results of the calculation of our selected key development indicators of six leading companies in Sumy region, the following conclusions can be done. Negative trends began to take shape before the crisis and military conflict in eastern Ukraine in 2014. This is evidenced by the negative values of ROE, EBITDA margin and EV / EBITDA multiplier for BELU, SFPF, VNDI. In general, these three companies have a relatively similar development trends over the analysed period. The improvement of the companies started in 2016-2017. The other three analysed companies (MDLZ, NEMS, TECH) are also relatively similar in terms of development dynamics: satisfactory indicators at the beginning of the analysed period began to get worse, but in 2016-2017 the situation stabilized. It should be noted that none of these companies showed a negative result in the group of performance indicators for the entire research period. It is worth mentioning the results of the company TECH, which in the period 2013-2106 improved these indicators, and after 2016 the indicators began to get worse, but remain mostly positive. The practical interest of future research is a more thorough and indepth analysis of the changes that have taken place within companies in this period. Equally interesting is the comparison of the enterprises analysed in this research with other enterprises in the relevant industry.

\section{References}

1. Bahatska, K.V., Hovorushko T.A., Sheremet O.O. (2014). Finansoviy analiz. Kyiv, 320 p.

2. Davydov O.I. (2017). Models of value added of enterprises: economic content and peculiarities of their construction. Naukovyy visnyk Mizhnarodnoho humanitarnoho universytetu 28(35), 167-172. 
Yuriy M. Derev yanko, Olha A. Lukash, Maryna A. Litsman, Alona O. Svitlychna. The State and Trends of Enterprises Efficiency on the Basis of Modern Indicators

3. Derev'yanko, Y.M. Companies' Innovative Development Trends in the Green Economy [Текст] / Y.M. Derev'yanko, O.A. Lukash, T.V. Marchenko // Механізм регулювання економіки. - 2016. - № 4. C. 77-85. http://essuir.sumdu.edu.ua/handle/123456789/66416

4. Kindratska L. M., Parasiy-Verhunenko I. M., Kalabukhova S. V. \& others (2017). Modernizatsiya analizu finansovoyi zvitnosti sub"yektiv hospodaryuvannya v umovakh innovatsiynoho rozvytku ekonomiky Ukrayiny, ed. L. M. Kindratska, Kyiv, KNEU, 481 p.

5. Luchko M. R., Zhukevych S. M., Farion A. I. (2016) Finansovyy analiz, Ternopil, TNEU, 304 p.

6. Finansovyy analiz promyslovykh pidpryyemstv (2016), ed. V.YA. Nusinova; Kryviy Rih, R. A. Kozlov, 511 p.

7. PJCS “Bel Shostka Ukraine”. URL: https://bel-ukraine.com/en/

8. PJCS "Mondelez Ukraine”, URL: https://ua.mondelezinternational.com

9. PJCS "Sumy Food Products Factory". URL: http://olivija.ua/

10. PJCS "VNDIkompressormash”. URL: http://www.nicmas.com/uk/golovna-storinka-2/

11. JCS “Nasosenergomash Sumy”. URL: http://nempump.com/

12. PJCS “Technologia”. URL: https://technologia.com.ua/

Manuscript received 19 March 2020

Стан та тенденції ефективності діяльності підприємств на основі сучасних індикаторів

\section{ЮРІй МИКОЛАЙОВИЧ ДЕРЕВ'ЯНКО,, ОЛЬГА АНАТОЛЇ̈ВНА ЛУКАШ ${ }^{* *}$, МАРИНА АНДРЇ̈вНА ЛІџМАН ${ }^{* * *}$, АЛЬОНА ОЛЕКСІївНА СвІтЛИчнА ${ }^{* * * *}$}

* кандидат економічних наук, дочент, доиент кафедри економіки та бізнес-адміністрування, Сумський державний університет,

вул. Р.-Корсакова, 2, м. Суми, 40007, Украӥна, тел.: 00-380-542-332223, e-mail: yuriy.m.derevyanko@gmail.com

*** кандидат економічних наук, доиент, доцент кафедри економіки та бізнес-адміністрування,

Сумський державний університет, вул. Р.-Корсакова, 2, м. Суми, 40007, Украйна, тел.: 00-380-542-332223, e-mail: olha.lukash@gmail.com

*** студент, Навчально-науковий інститут бізнес-технологій "УАБС",

Сумський державний університет,

вул. Петропавлівська, 57, м. Суми, 40030, Україна, тел.: 00-380-542-665037, e-mail: litsmanmarina01@gmail.com

***** студент, Навчально-науковий інститут бізнес-технологій "УАБС", Сумський державний університет, вул. Петропавлівська, 57, м. Суми, 40030, Украӥна тел.:00-380-542-665037,e-mail: alyonasvitl@gmail.com

Одним із найбільш актуальних підходів до визначення ефективності діяльності справедливо вважаються привабливість компанії 3 точки зору інвестування у неї коштів та отримання винагороди власниками чи менеджерами компанії. 3 цих позицій, можна виокремити чотири групи показників аналізу ефективності: показники зростання (виручка / дохід від продаж, чистий 
Ю. М. Дерев'янко, О. А. Лукаш, М. А. Ліџман, А. О. Світлична.

Стан та тенденції ефективності діяльності підприємств на основі сучасних індикаторів

прибуток, EBIT, EBITDA, FCF та OCF, CAPEX (OPEX); показники ефективності (ROE, EBIT margin, EBITDA margin, рентабельність чистого доходу); показники оцінки стану (мультиплікатори та недооцінки) (EV/EBITDA, P/E, P/BV, FCF Yield, FCF/MC, EV/виручка, рентабельність за дивідендами); показники боргового навантаження та ризикованості (чистий борг/EBITDA, власний капітал/активи, стандартне відхилення, коефіцієнт бета). Сучасний стан розвитку української економіки вимагає застосування відповідних інструментів аналізу, які дозволяють об'єктивно оцінити поточний стан бізнесу та оцінити в динаміці зміни, що відбулися раніше. Нами було обрано період аналіз із 2013 по 2019 рік, щоб оцінити ті зміни, які відбулися за цей проміжок часу, який почався за відносно стабільної економічної ситуації та переріс в потужну економічну кризу зумовлену, перш за все, подіями на сході України та анексією Криму. Метою оцінки стану розвитку та привабливості українських підприємств $€$ перевірка факту подолання активної фази кризи 20142016 pp. 3 цією метою ми зосередилися на аналізі провідних компаній Сумської області, адже вони мали тісні зв'язки з Російською федерацією, та досить часто регіон асоціюється із регіонами 3 досить посередніми рівнем розвитку бізнесу, а отже може бути, таким собі індикатором усередненого стану економіки країни в цілому. Проведений аналіз компаній за відібраними основними показниками вказує, що криза була переважно подолана, однак ряд індикаторів частини компаній вказує, що криза почалася ще до початку трагічних подій початку 2014 року.

Ключові слова: ефективність, індикатор, менеджмент, підприємство.

Mechanism of Economic Regulation, 2020, No 1, 106-115 ISSN 1726-8699 (print)

Состояние и тенденции эффективности деятельности предприятий на основе современных индикаторов

\section{ЮРИЙ НИКОЛАЕВИЧ ДЕРЕВЯНКО*, \\ ОЛЬГА АНАТОЛЬЕВНА ЛУКАШ ${ }^{* *}$, МАРИНА АНДРЕЕВНА ЛИЦМАН ${ }^{* * *}$, АЛЁНА АЛЕКСЕЕВНА СвИТЛИЧнАЯ $\Re^{* * * *}$}

* кандидат экономических наук, дочент, доиент кафедры экономики и бизнес-администрирования,

Сумский государственный университет, ул. Р.-Корсакова, 2, г. Сумы, 40007, Украина, тел.: 00-380-542-332223, e-mail: yuriy.m.derevyanko@gmail.com

** кандидат экономических наук, дочент дочент кафедры экономики и бизнес-администрирования,

Сумский государственный университет,

ул. Р.-Корсакова, 2, г. Сумыл, 40007, Украина, тел.: 00-380-542-332223, e-mail: olha.lukash@gmail.com

**** студент, Учебно-научный институт бизнес-технологий "УАБС",

Сумский государственный университет,

ул. Петропавловская, 57, г. Сумы, 40007, Украина, тел.: 00-380-542-665037, e-mail: litsmanmarina01@gmail.com

**** студент, Учебно-научный институт бизнес-технологий "УАБС",

Сумский государственный университет

ул. Петропавловская, 57, г. Сумы, 40007, Украина,

тел.: 00-380-542-665037, e-mail: alyonasvitl@gmail.com 
Yuriy M. Derev yanko, Olha A. Lukash, Maryna A. Litsman, Alona O. Svitlychna. The State and Trends of Enterprises Efficiency on the Basis of Modern Indicators

Одним из самых актуальных подходов к определению эффективности деятельности справедливо считается привлекательность компании с точки зрения инвестирования в неё средств и получения вознаграждения владельцами или менеджерами компании. С этих позиций, можно выделить четыре группы показателей анализа эффективности: показатели роста (выручка / доход от продаж, чистая прибыль, EBIT, EBITDA, FCF и OCF, CAPEX (OPEX) показатели эффективности (ROE, EBIT margin, EBITDA margin, рентабельность чистого дохода); показатели оценки состояния (мультипликаторы и недооценка) (EV/EBITDA, P/E, P/BV, FCF Yield, FCF/MC, EV/выручка, рентабельность по дивидендам) показатели долговой нагрузки и рискованности (чистый долг/EBITDA, собственный капитал/активы, стандартное отклонение, коэффициент бета). Современное состояние развития украинской экономики требует применения соответствующих инструментов анализа, которые позволяют объективно оценить текущее состояние бизнеса и оценить в динамике изменения, произошедшие ранее. Нами был выбран период анализ с 2013 по 2019 год, чтобы оценить те изменения, которые произошли за этот промежуток времени, который начался с относительно стабильной экономической ситуации и перерос в мощный экономический кризис обусловленный, прежде всего, событиями на востоке Украина и аннексией Крыма. Целью оценки состояния развития и привлекательности украинских предприятий является проверка факта преодоления активной фазы кризиса 2014-2016 гг. С этой целью мы сосредоточились на анализе ведущих компаний Сумской области, ведь они имели тесные связи с Российской Федерацией, и довольно часто регион ассоциируется с регионами с достаточно посредственными уровнем развития бизнеса, а значит, может быть, неким индикатором усредненного состояния экономики страны в целом. Проведенный анализ компаний по отобранным основным показателям указывает, что кризис был преимущественно преодолён, однако ряд индикаторов части компаний указывает, что кризис начался еще до начала трагических событий начала 2014 года.

Ключевые слова: индикатор, менеджмент, предприятие, эффективность.

JEL Code: C51, G01, G30

Figures: 2; Tables: 2; References: 12

Language of the article: English 